\title{
Green Supply Chain Management Practice of FDI Companies in Vietnam
}

\author{
Van Loi TA ${ }^{1}$, Huy Nhuong BUI ${ }^{2}$, Chi Dung CANH ${ }^{3}$, Thi Dung DANG ${ }^{4}$, Anh Duc DO ${ }^{5}$ \\ Received: August 01, 2020 Revised: September 06, 2020 Accepted: September 10, 2020
}

\begin{abstract}
This paper aims to develop a conceptual framework for Green Supply Chain Management (GSCM) that takes into account the effect of GSCM drivers on implementing GSCM practices in Vietnam FDI companies. This study has considered organizational commitment, social network, and government support as GSCM driver factors and proposed a structural model of the relationships between GSCM drivers and GSCM practices in Vietnam FDI companies. The empirical analysis used data from 192 questionnaires which used a comprehensive, valid, and reliable tool (SPSS 26 and SmartPLS 3.0 software) to evaluate rigorous statistical tests including convergence validity, discriminatory validity, reliability, and Average Variance Extracted (AVE) to analyze and verify the gathered data and develop the hypothesis. The result of path analysis shows that GSCM driver factors constitute a structured system with different degrees of influence on GSCM drivers and GSCM practices. Organizational commitment and government support has a positive relationship with both GSCM drivers and GSCM practices, while social network only has a positive relationship on GSCM drivers. As a result, the testing of the relationship between GSCM drivers and GSCM practices has been verified and supported. The findings of this study can help managers and decision-makers to push the implementation of GSCM practices in FDI companies.
\end{abstract}

Keywords: GSCM, GSCM Drivers, GSCM Practices, FDI Companies, Vietnam

JEL Classification Code: M11, M14, M16, L1

\section{Introduction}

In recent decades, the global economy has developed rapidly; however, people only pay attention to the importance of economic development, while ignoring the protection of the

${ }^{1}$ First Author. Associate Professor, Dean, School of Trade and International Economics, National Economics University, Vietnam. Email: loitv@neu.edu.vn

${ }^{2}$ Associate Professor, Head of Personal and Organizational Department, National Economics University, Vietnam.

Email: nhuongbh@neu.edu.vn

${ }^{3}$ Deputy Director General, Personnel and Organization Department, Ministry of Education and Training, Vietnam.

Email: dungcc@moet.gov.vn

${ }^{4} \mathrm{PhD}$ Candidate. National Economics University, Vietnam. Bac Ninh Center for Rural Water Supply and Environmental Sanitation.

Email: dungtriphuong@gmail.com

${ }^{5}$ Corresponding Author. Doctor, School of Trade and International Economics, National Economics University, Vietnam [Postal Address: 207 Giai Phong Road, Dong Tam Ward, Hai Ba Trung District, Hanoi, 116000, Vietnam] Email: ducda@neu.edu.vn

(c) Copyright: The Author(s)

This is an Open Access article distributed under the terms of the Creative Commons Attribution Non-Commercial License (https://creativecommons.org/licenses/by-nc/4.0/) which permits unrestricted non-commercial use, distribution, and reproduction in any medium, provided the original work is properly cited. ecological environment. In developing countries, this situation is becoming increasingly serious because natural resources are slowly depleting and environmental problems are increasing. Hence, Green Supply Chain Management (GSCM) as a feasible way to reduce the environmental problems and spur economic growth, create competitive advantage in terms of greater customer satisfaction, positive image and reputation, has been gaining much traction among practitioners and researchers (Srivastava, 2007; Seuring \& Muller, 2008; Sarkis, 2012; Tate et al., 2012; Fahimnia et al., 2015). Previous research on GSCM extensively discusses GSCM drivers that drive companies to implement GSCM practices (Handfield et al., 2005; Zhu \& Sarkis, 2004; Zhu et al., 2013; Hoejmose et al., 2014). Existing studies also point out that the success of a company in implementing GSCM practices and achieving the targeted performance objectives could be hindered or encouraged by the effect of influential factors. Do et al. (2020) stated that GSCM creates a rebuilding system for a bright way. However, implementing and achieving GSCM is not an easy task. There is still a need for a better understanding of how GSCM drivers and its factors in isolation as well as jointly impact the success of the company in implementing GSCM practices. Specifically, GSCM practices in Vietnam FDI companies were relatively unexplored. 
Vietnam has been quite successful in attracting FDI inflows since the inception of economic reform (known as "doi moi") in 1986. Up to now, the FDI sector has affirmed the major role it plays in the Vietnamese economy. Vietnam has become an attractive destination (Ta et al., 2020) and continues to attract record FDI. According to official statistics released from the Ministry of Planning and Investment, FDI in Vietnam in 2019 reached USD 38.2 billion (increase by $7.2 \%$ as compared to the same period in 2018). Vietnam has 30.827 valid projects with a total registered capital of USD 362.58 billion, in which the accumulated realized capital of FDI projects is estimated at USD 211.78 billion, equaling $58.4 \%$ of total valid registered capital. However, the focus has been only on FDI attraction for growth targets without paying attention to environmental protection which that Vietnam is facing serious consequences. In Vietnam's sustainable development strategy for 2011-2020, the Vietnamese government has pointed out that the environment in many places is heavily polluted, and resources and land are not well managed due to ineffective exploitation and use of natural resources and land. This situation necessitates Vietnam to restructure its economy, implement in-depth growth model of transformation and implement greening the economy including green production, green consumption, and green lifestyles to ensure sustainable development. These tasks are expected such that Vietnam FDI companies will need to implement strategies to reduce the environmental impacts of their products and services. Approaches to the effectiveness of green activities' implementation comprise green purchasing, green production, environmental management systems and eco-efficiency, etc. Vietnam FDI companies have implemented GSCM practices. Furthermore, through the advantage of GSCM practices, FDI companies can select from a wide variety of suppliers and eliminate the environmental impacts of supply chain activities. Unfortunately, there are few papers to investigate the effects of institutional pressures on GSCM drivers and on GSCM practices simultaneously (Sarkis et al., 2011), and research on GSCM practices in Vietnam FDI companies is relatively immature. Moreover, GSCM in Vietnam has not received strong attention from policy-makers, businesses, and researchers (Le, 2020).

This study is intended to address this gap. Consequently, an extensive literature review of GSCM drivers and GSCM practices was carried out and the relationship between GSCM drivers and GSCM practices were identified as the way to improve the GSCM capabilities of Vietnam FDI companies. This study develops a conceptual framework for GSCM that takes into account the effect of GSCM drivers on implementing GSCM practices in Vietnam FDI companies. Through an empirical investigation using the PLS-SEM methods, this study contributes to understanding how the influential factors of GSCM drivers interact with each other and affect the GSCM practices in Vietnam FDI companies. The rest of this paper is organized as follows: section 2, introduces the literature review and propose a structural model for the GSCM in Vietnam FDI companies; section 3, introduces the methodology, explains how we used it in this study; section 4, presents the results of our study; and section 5 , certain conclusions are drawn, and potential issues and opportunities in the realm of GSCM practices are identified.

\section{Literature Reviews}

\subsection{Overviews of Green Supply Chain Management (GSCM)}

The term, "supply chain management" is a relatively new business phrase that has evolved over the past three decades. Supply chain management gained popularity because it evolved in both the academic and practitioner contexts. The evolution of supply chain management can be traced to the early industrial age with the culmination of scientific industrial practices and vertical integration. The boundary and definitions of supply chain management have always been a crux of the field. Lambert and Enz (2015) stated that the term, "supply chain management" continues to evolve, with some calls for linkage and relationships to logistics and marketing requiring further clarification.

In 1994, Webb (1994) proposed the concept of green procurement when he studied the impact that some products cause to the environment, and he recommended companies should select the appropriate raw materials by the environmental criteria, and focus on recycling. Following, Handfield et al. (1996) put forward the concept of a green supply chain and put the green supply chain as an important research content. Meanwhile, the International Organization for Standardization (ISO) launched a series of ISO14000 standard in 1996, led too much more active studies about the green supply chain. Min and Galle (1997) discussed how to consider environmental factors in selecting the suppliers and the green procurement's role in reducing waste. In 1998, Professor Sarkis from the United States Clark University proposed the concept of GSCM and pointed out that green supply chain includes the following major components: internal logistics and procurement, materials management, external logistics, packaging, and return logistics (Sarkis, 1998). Beamon (1999) considered the environmental factors in the supply chain model, and put forward the more extensive supply chain design mode.

Recently, driven by the accelerated deterioration of the environment and multiple markets and non-market pressures (Zhu et al., 2013), GSCM has been gaining much traction among practitioners and researchers alike and received multiple definitions (Ahi \& Searcy, 2013) and literature on this topic has often been reviewed (Srivastava, 2007; 
Seuring \& Muller, 2008; Sarkis et al., 2011; Tate et al., 2012; Fahimnia et al., 2015). The common understanding of GSCM is the integration of environmental issues and concerns into supply chain management (Stock \& Boyer, 2009; Mentzer et al., 2001) to improve the environmental impact of the activities of the supply chain while maintaining competitiveness and achieving economic and operational performance criteria (Beamon, 1999; Sarkis, 2003; Zhu \& Sarkis, 2004; Rao \& Holt, 2000; Srivastava, 2007; Large \& Thomsen, 2011; Wang \& Sarkis, 2013; Lee, 2015).

\subsection{GSCM Practices}

Due to the rising global awareness of environmental protection, companies have implemented their GSCM practices enhancing their core competitive advantage and environmental protection. Zhu and Sarkis (2004) developed a conceptual framework for GSCM including two categories of performance outcomes: environmental and economic performance. Similarly, Rao and Holt (2005) suggested and tested a conceptual model of GSCM that included practices related to green the inbound phase of the supply chain and greening the production phase or the internal supply chain; and greening the outbound phase of the supply chain. Zhu et al. (2005) proposed four ways to implement GSCM practices: internal environmental management; external GSCM; eco-design; and investment recovery. Zhu and Sarkis (2006) have defined GSCM practices as containing source management, supply chain integration and reverse logistics. Regarding the difference between cross-countries GSCM practices, Zhu and Sarkis (2006) and Zhu et al. (2007), both investigated the GSCM practices of China's manufacturing industries and discovered that investment recovery and eco-design were significant for all surveyed industries, but the significance of other GSCM practices depended on the industries themselves. Therefore, GSCM practices are best viewed as a cross-organizational and closed-loop which allows supply chain members to protect the environment and collaborate along the supply chain (Zhu et al., 2008).

Summarizing the previous studies, we assume that GSCM practices are developed with the items be classified into: (i) environmental management systems exist, (ii) cooperation with suppliers for environmental objectives (friendly goods and packages), and (iii) cooperation with customer for green design, produce, and packages. (Zhu et al., 2008; Chen et al., 2019, Laari, 2016; Mahmoud Hamdy et al., 2018).

\subsection{GSCM Drivers}

These are a number of other forces are causing companies to pay greater attention to GSCM practices. GSCM drivers can be classified into main factors as follows:
Organizational commitment: The GSCM has become a mainstay of green business models and it is involved in organizational re-engineering of business strategies and in manufacturingprocesses. Therefore, companiescannotengage in GSCM practices without organizational commitment. Zhu et al. (2008) showed that the management commitment is a critical factor in the successful implementation of GSCM practices. Furthermore, senior managers' commitments to GSCM can make organizations adopt appropriate environmental management systems (Ramus \& Steger, 2000). Moreover, the environmental management system is a kind of organizational learning mechanism which not only can construct environmental standards to prevent pollution but also can strengthen companies' capacities for continuous improvement to implement GSCM practices (Sharma et al., 1999; Zhu et al., 2008). Organizational internal resources are essential for organizations to adopt proactive environmental strategies. Consequently, these organizational commitments are indivisible and correlated with GSCM practices. According to Lee (2008), the greater the GSCM readiness, the more willing companies are to implement GSCM practices. Gonzalez-Torre et al. (2010) indicated that if companies wanted to implement GSCM practices, they had to overcome organizational internal obstacles such as lack of top management commitment, lack of environmental professional knowledge, lack of information and technological systems and costly financial and human resources. Therefore, organizational commitment is considered as the main factor of GSCM driver.

Social network: In the context of globalization and integration, supply chain management is a crossorganizational activity, FDI companies need to cooperate with their supply chains partners to engage in GSCM practices. The social network suggests that companies should establish social relationships with their supply chains partners through communication, trust, and values. Meanwhile, Luk et al. (2008) mentioned a social networkbased benefit embedded in relationships with managers at other companies and relationships with government officials which can help organizations achieve knowledge sharing and mutual collaboration. GSCM practices involve many environmental management practices. Companies must build a social network with their supply chains partners to decrease information asymmetry, have more confidence in partners, establish long-term relationships with partners and improve collaboration (Claro et al., 2006). While having good social relationships with supply chain partners, companies will be more inclined to share their knowledge and collaborate (Tsai \& Ghoshal, 1998; Lawson et al., 2008). Among the social relationships, Krause et al. (2007) showed that companies and their partners will have the same goals and visions which help companies exchange their resources and integrate their 
potential benefits. Further, when supply chain members perform these behaviors, the benefits of the social network will improve the supply chain collaboration (Krause et al., 2007; Lawson et al., 2008). Therefore, the social network is considered as the main factor of GSCM driver.

Government support: Government indeed plays an important role in the implementing GSCM practices. Porter (1990) noted that the government can also help companies transform their business models through technical and financial support. Holt et al. (2001) stated that government support has improved companies' environmental performance. Government support, such as increasing awareness of environmental management knowledge, collaborating with GSCM initiatives and offering financial resources, can persuade companies to implement GSCM practices (Lee, 2008). Government grants and technical support could not only reduce a company's expenses and technical uncertainties but also help that company implement GSCM practices (Darnall, 2003; Darnall \& Edwards, 2006). Vietnam's government indeed plays an important role in the development of Vietnam FDI companies and engage GSCM practices meeting environmental standards in response to the green environmental protection trend of the international market. Government supports FDI companies to improve companies technology and R\&D capabilities to produce higher quality and value-added products which give companies a larger share in the global R\&D and capabilities. Moreover, the government can provide incentives for FDI companies improved their $\mathrm{R} \& \mathrm{D}$ of green products to reduce pollution and conserve natural resources or invest in the infrastructure to improve the industrial environment. Therefore, the government support is considered as the main factor of GSCM driver.
According to the above statement, our research assumes that organizational commitment, social network, and government support can form a consensus between Vietnam FDI companies and their supply chains partners and implement GSCM practices. Among the GSCM drivers of this research, organizational commitment is internal complementary resources which can help department members arrive at a consensus on the environmental issues (Zhu et al., 2008, 2005). The social network is a relationshipspecific asset. With mutual trust, the social network can help companies build up collaboration among supply chain partners (Krause et al., 2007; Lawson et al., 2008). The government support is an auxiliary resource, which can provide the professional knowledge and financial resources for companies and coordinate actions taken by GSCM partners (Lee, 2008).

\subsection{Conceptual Framework}

Hart (1995) stated that companies must assert product stewardship and the strategic capability of pollution prevention to achieve sustainable development. Product stewardship requires not only coordinating functional groups within a firm, but also cooperating with suppliers and customers to design to the environment. Pollution prevention is usually entangled with manufacturing and requires the sharing of tacit knowledge and continuous process reengineering through an environmental management system. Tate et al. (2012) emphasized that a growing part of the theoretical and empirical research in GSCM is dedicated to exploring the drivers (motivations or pressures) for adopting and applying GSCM practices.

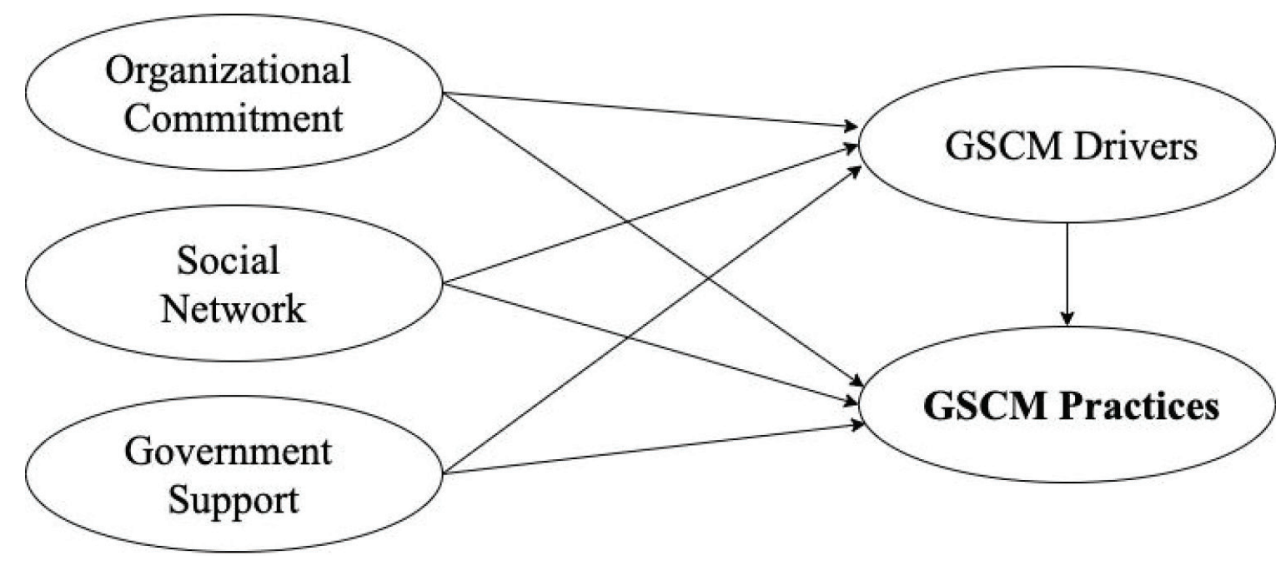

Figure 1: The proposed structural model 
Grounding our arguments in the extensive literature review, and invoking the contingency theory perspective, we suggested that the GSCM drivers include the three main factors as identified above. Therefore, understanding these factors is crucial to comprehend the underlying reasons for different levels of success in implementing GSCM practices in Vietnam FDI companies, even when they face similar pressures and pursue similar objectives. We suggest a conceptual framework for GSCM in Vietnam FDI companies (see Figure 1). This framework recognizes and takes into account the causal relationship between the above mentioned GSCM drivers with the three factors and GSCM practices. Nevertheless, the empirical investigation of such factors is relatively scant, and the rare existing studies (Diabat \& Govindan, 2011; Luthra et al., 2015) often confound different elements of GSCM such as practices and drivers. Consequently, there is a need for an in-depth and systematic investigation of these factors taken together to study how they interact with each other, and how they affect the GSCM drivers and the related GSCM practices. Further, based on the above statements of GSCM drivers and GSCM practices, this research presents the following hypotheses:

H1: Organizational commitment has a positive relationship with GSCM drivers and GSCM practices.

H2: Social network has a positive relationship with GSCM drivers and GSCM practices.

H3: Government support has a positive relationship with GSCM drivers and GSCM practices.

H4: GSCM drivers have a positive relationship with GSCM practices.

\section{Methodology}

\subsection{Research Sample}

Our objective was to develop a conceptual GSCM practices framework in Vietnam FDI companies based on the extant literature. We conducted a literature review to search for ideas and gaps in the GSCM practices framework. We identified key categories of the GSCM practices framework and derived research questions to expand the understanding of the GSCM practices in Vietnam FDI companies. The questionnaires were distributed first to 20 experts to check how they understand the questions. Afterwards, we revised the final questionnaires form based on the suggestions from respondents in two workshops and use it for collecting data.

According to Hair et al. (2014), the research sample is a very important factor to ensure the quality of the research. The minimum sample size should be 10 times the maximum number of arrowheads pointing at a latent variable anywhere in the PLS path model (Hair et al., 2014). We collected 200 samples of survey questions from different managers of FDI companies in the northern Vietnam. In that, 198 survey forms were sent back to us, in which 192 ones were valid for analysis which represents $96 \%$. Table 1 , shows the respondent information.

A sector of the companies fell into the industry, representing 28.1\%; services account sector for the most $(70.3 \%)$; and $1.6 \%$ belong to agriculture. Regard to the size of company (represented by the number of employees), $4.2 \%$ were companies that have more than 1000 employees, companies that have 100 to 1000 employees account for $87.5 \%$ and companies that have less than 100 employees companies account for $8.3 \%$ in this study.

Table 1: Respondent information

\begin{tabular}{|l|l|c|c|}
\hline & & Frequency & Percent (\%) \\
\hline \multirow{3}{*}{ Gender } & Male & 116 & 60.4 \\
\cline { 2 - 4 } & Female & 76 & 39.6 \\
\hline \multirow{4}{*}{ Busperience } & $<5$ years & 11 & 5.8 \\
\cline { 2 - 4 } & $5-10$ years & 142 & 73.9 \\
\cline { 2 - 4 } & $>10$ years & 39 & 20.3 \\
\hline \multirow{3}{*}{$\begin{array}{l}\text { Size of company (Numper of } \\
\text { employees) }\end{array}$} & Industry & 54 & 28.1 \\
\cline { 2 - 4 } & Agriculture & 3 & 1.6 \\
\cline { 2 - 4 } & Services & 135 & 70.3 \\
\cline { 2 - 4 } & $<100$ employees & 16 & 8.3 \\
\cline { 2 - 4 } & $100-1000$ employees & 168 & 87.5 \\
\cline { 2 - 4 } & $>1000$ employees & 8 & 4.2 \\
\hline
\end{tabular}




\subsection{Data Analysis Techniques}

Our research has provided some empirical evidence for a framework that identifies key aspects of GSCM and describes the relationship between GSCM drivers and GSCM practices. After collecting the result of survey questionnaires, the data was encrypted, cleaned, and then imported into SPSS for reliability analysis and EFA discovery factor analysis. Then, we used a comprehensive, valid, and reliable tool (SPSS 26 and SmartPLS 3.0 software) to evaluate rigorous statistical tests including convergence validity, discriminatory validity, reliability, and AVE to analyze and verify the gathered data, and the hypothesis developed.

\section{Data Analysis}

\subsection{Reliability and Validity of Model}

Construct validity, determined through the presence of convergent and discriminant validity, demonstrates how well the measurement items related to the constructs. To demonstrate convergent validity, we used three tests: item reliability, composite reliability, and AVE. Cronbach's alphas also provide evidence of composite reliability and values above 0.6 demonstrate that it is adequate. The results in Table 2, showed that all the composite reliabilities for our constructs were above 0.7 and all the Cronbach's alphas were above 0.6. The AVE represents the number of variance a construct captures via its items relative to the number of variation dues to measurement error. We found that each construct's variance extracted was above the recommended value of 0.5 (Hair et al., 2016). Thus, we have concluded that all our constructs had satisfactory convergent validity.

For testing the discriminant validity, we used two tests for discriminant validity: comparison of item loadings with item cross-loadings and comparison of the variance extracted from the construct with shared variance. Each item should load more highly on its intended construct than on other constructs. The top coefficients that are larger than the correlation coefficients in the same column (Fornell-Larcker matrix coefficient) have satisfied the condition as suggested by Henseler et al. (2015). The result from Table 3 showed that all items satisfied the condition of discriminant validity.

\subsection{PLS Structural Model Results}

We next examined the overall explanatory power of the structural model and explained the variance by the independent variables, and the magnitude and strength of its paths, where each of our hypotheses corresponds to a specific structural model path. We used R Square Adjusted to measure the model's explanatory power, interpreted in the same way as for regression analysis. The analysis revealed that the structural model explained about $64 \%$ of the variation of GSCM drivers, $85.3 \%$ of the variation in GSCM practices, suggesting that the structural model provided adequate explanatory (see Table 4).

To evaluate the structure model, we conducted the test with sample size Bootstrapping $\mathrm{N}=5000$ (Henseler et al., 2015). With p-value $<1 \%, 5 \%$, and $10 \%$, the proposed hypotheses are considered as statistically significant at the $99 \%, 95 \%$ and $90 \%$ reliability levels. The result is as follows:

Table 2: Construct Reliability and Validity

\begin{tabular}{|l|c|c|c|c|}
\hline & Cronbach's Alpha & rho_A & $\begin{array}{c}\text { Composite } \\
\text { Reliability }\end{array}$ & $\begin{array}{c}\text { Average Variance } \\
\text { Extracted (AVE) }\end{array}$ \\
\hline Organizational Commitment & 0.817 & 0.824 & 0.879 & 0.647 \\
\hline Social Network & 0.791 & 0.805 & 0.878 & 0.706 \\
\hline Government Support & 0.812 & 0.832 & 0.888 & 0.727 \\
\hline GSCM Drivers & 0.814 & 0.815 & 0.890 & 0.729 \\
\hline GSCM Practices & 0.782 & 0.787 & 0.874 & 0.699 \\
\hline
\end{tabular}

Table 3: Discriminant validity (Fornell-Larcker Criterion)

\begin{tabular}{|l|c|c|c|c|c|}
\hline & $\begin{array}{c}\text { Organizational } \\
\text { Commitment }\end{array}$ & Social Network & $\begin{array}{c}\text { Government } \\
\text { Support }\end{array}$ & GSCM Drivers & $\begin{array}{c}\text { GSCM } \\
\text { Practices }\end{array}$ \\
\hline Organizational Commitment & 0.804 & & & & \\
\hline Social Network & 0.193 & 0.840 & & & \\
\hline Government Support & 0.057 & 0.312 & 0.852 & & \\
\hline GSCM Drivers & 0.484 & 0.659 & 0.471 & 0.854 & \\
\hline GSCM Practices & 0.524 & 0.628 & 0.491 & 0.914 & 0.836 \\
\hline
\end{tabular}


Table 4: $\mathrm{R}$ square

\begin{tabular}{|l|c|c|}
\hline & R Square & R Square Adjusted \\
\hline GSCM Drivers & 0.645 & 0.640 \\
\hline GSCM Practices & 0.856 & 0.853 \\
\hline
\end{tabular}

Table 5: Hypothesis result.

\begin{tabular}{|c|c|c|c|c|c|c|}
\hline & $\begin{array}{l}\text { Original } \\
\text { Sample (0) }\end{array}$ & $\begin{array}{l}\text { Sample } \\
\text { Mean (M) }\end{array}$ & $\begin{array}{l}\text { Standard } \\
\text { Deviation } \\
\text { (STDEV) }\end{array}$ & $\begin{array}{c}\text { T Statistics } \\
(\mid \mathrm{O} / \\
\text { STDEV|) }\end{array}$ & P Values & $\begin{array}{l}\text { Hypothesis } \\
\text { result }\end{array}$ \\
\hline $\begin{array}{l}\text { Organizational Commitment -> } \\
\text { GSCM Drivers }\end{array}$ & 0.372 & 0.372 & 0.045 & 8.219 & 0.000 & \multirow{2}{*}{ Supported } \\
\hline $\begin{array}{l}\text { Organizational Commitment -> } \\
\text { GSCM Practices }\end{array}$ & 0.144 & 0.145 & 0.031 & 4.600 & 0.000 & \\
\hline Social Network -> GSCM Drivers & 0.495 & 0.491 & 0.048 & 10.358 & 0.000 & \multirow{2}{*}{$\begin{array}{c}\text { Partly } \\
\text { Supported }\end{array}$} \\
\hline Social Network -> GSCM Practices & 0.078 & 0.081 & 0.040 & 1.936 & 0.053 & \\
\hline $\begin{array}{l}\text { Government Support -> GSCM } \\
\text { Drivers }\end{array}$ & 0.296 & 0.299 & 0.044 & 6.741 & 0.000 & \multirow{2}{*}{ Supported } \\
\hline $\begin{array}{l}\text { Government Support -> GSCM } \\
\text { Practices }\end{array}$ & 0.109 & 0.111 & 0.036 & 3.028 & 0.002 & \\
\hline GSCM Drivers -> GSCM Practices & 0.741 & 0.737 & 0.043 & 17.434 & 0.000 & Supported \\
\hline
\end{tabular}

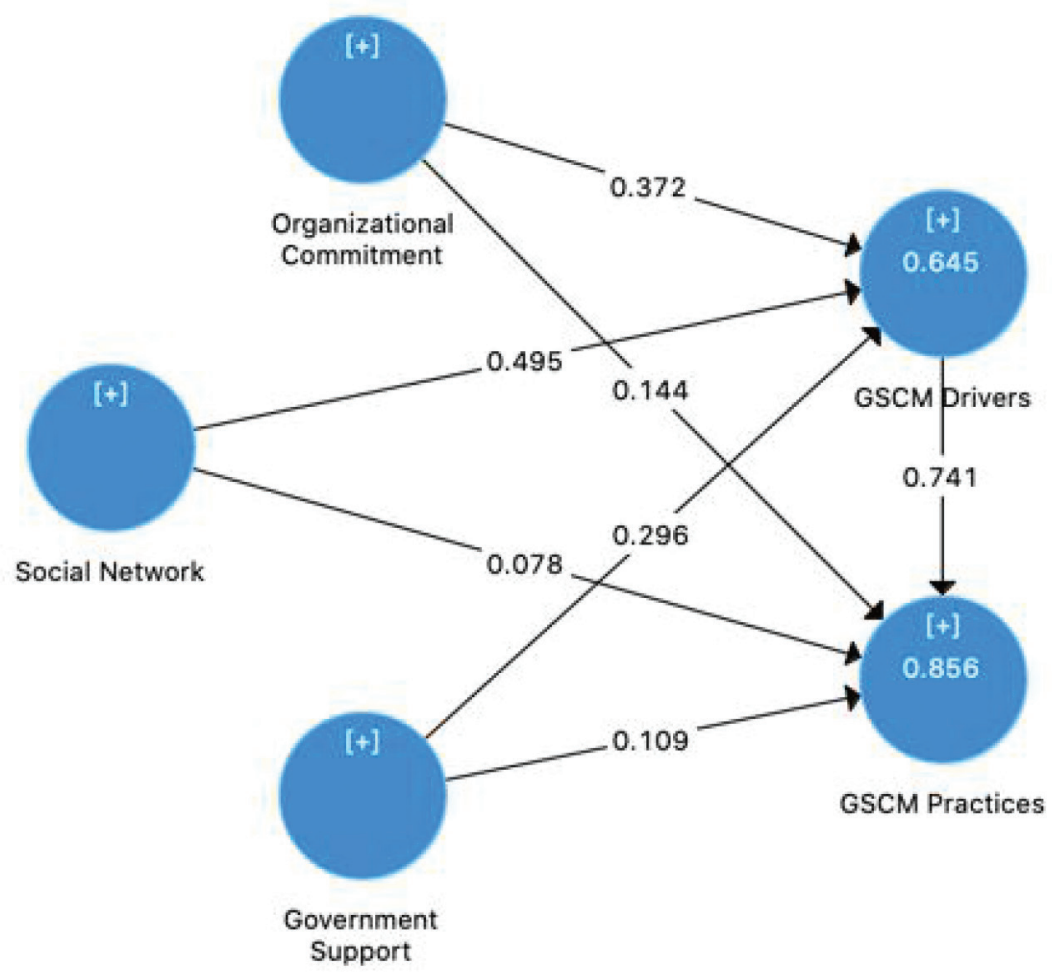

Figure 2: Research model result 
The result from Table 5 and Figure 2 indicates that three in four hypotheses in our conceptual model is fully supported, one hypotheses is partly supported. $\mathrm{H}_{1}$ shows that organizational commitment has a positive relationship with GSCM drivers $(\beta=0.372, \mathrm{t}=8.219, \mathrm{P}<0.01)$ and GSCM practices $(\beta=$ $0.144, \mathrm{t}=4.6, \mathrm{P}<0.01)$. This result shows that if organizational commitment is improved, the GSCM drivers and practices are also improved. $\mathrm{H}_{2}$ estimations for the relationships of the among social network with GSCM drivers and GSCM practices are partly supported while the prediction of the relationship between the social network and GSCM drivers have supported $(\beta=0.495, \mathrm{t}=10.358, \mathrm{P}<0.01)$. However, the prediction of relationship between the social network and GSCM practices are not supported $(\mathrm{P}>0.05)$. This result notes that the social network may make the GSCM drivers but may not have the result of GSCM practices. The results of $\mathrm{H}_{3}$ shows the positive relationship between the government support and GSCM drivers $(\beta=0.296, \mathrm{t}=6.741, \mathrm{P}<0.01)$ and the relationship between government support and GSCM practices $(\beta=0.109$, $\mathrm{t}=3.028, \mathrm{P}<0.01)$ This result indicates government support has impacted on both GSCM drivers and GSCM practices of FDI companies. Finally, the testing of the relationship between GSCM drivers and GSCM practices has been verified and is supported $\left(\mathrm{H}_{4}: \beta=0.741, \mathrm{t}=17.434, \mathrm{P}<0.01\right)$.

\section{Conclusions}

GSCM practices are a green revolution at the supply chain level and the implementing GSCM practices are increasingly becoming a major objective for manufacturers to respond to institutional pressures (Zhu et al., 2013). Alternatively, Handfield et al. (2005) emphasized that some companies are proactively implementing GSCM practices to gain a competitive advantage. Hence, this research proposed an empirical investigation to study the effects of GSCM drivers and its factors on GSCM practices simultaneously, push Vietnam FDI companies to implement GSCM practices. Understanding how these factors affect the implementation of GSCM practices should help managers to concentrate their efforts and efficiently allocate resources to attain the objective. This research has also improved the previous research model in GSCM drivers and GSCM practices in the context of the research concerning GSCM in developing countries has been insufficient (Mitra \& Datta, 2014).

Based on the literature review, this study has considered organizational commitment, social network and government support as GSCM drivers factors, and proposed a structural model of the relationships among GSCM drivers and these factors with GSCM practices in Vietnam FDI companies. Applying SPSS 26 and Smart PLS 3.0, this study has used a comprehensive, valid and reliable tool to evaluate rigorous statistical tests including convergence validity, discriminatory validity, reliability and AVE. The result of the path analysis indicates that three in four hypotheses in our conceptual model is fully supported, one hypothese is partly supported. Among the findings of our work, we note in particular, the influence of the relationships between GSCM drivers and its factors on the implementation of GSCM practices. Taken together, GSCM driver factors constitute a structured system with different degrees of influence on GSCM drivers and GSCM practices. We especially found that organizational commitment and government support have a positive relationship with both GSCM drivers and GSCM practices. However, social network only has a positive relationship with GSCM drivers. As a result, the testing of the relationship between GSCM drivers and GSCM practices has been verified and supported. This finding corroborates the findings in Handfield et al. (2005); Zhu \& Sarkis (2004); Zhu et al. (2013a); and Hoejmose et al. (2014) study in that GSCM drivers push companies to try to implement GSCM practices. Moreover, the findings of this study broadly support the related literature regarding the influence of each one of the factors on the implementation of GSCM practices. The results of this study are important since Vietnam has been quite successful in attracting FDI inflows but GSCM practices in Vietnam FDI companies has not received strong attention by researchers. On one hand, these results offer several insights for managers and decision-makers to push the implementation of GSCM practices in FDI companies. On the other hand, by focusing on the factors identified in this research, GSCM practices can be implemented more effectively.

Despite several contributions emanating from this study, the structural model should be more developed regarding other impacting factors in the future. Further researches could explore different conceptual models of GSCM performance, after implementation of the critical factors is carried out. Furthermore, due to the novelty of GSCM adoption in Vietnam FDI companies, future studies with larger samples could be conducted to allow for comparisons of GSCM practices among companies in other sectors in Vietnam.

\section{References}

Ahi, P., \& Searcy, C. (2013). A comparative literature analysis of definitions for green and sustainable supply chain management. Journal of Cleaner Production, 52, 329-341.

Beamon, B. M. (1999). Designing the green supply chain. Logistics information management, 12(4), 332-342

Bilici, H., Ta, L., \& Carcamo, B. (2017). Impact of Foreign Direct Investment and Barriers to MNC Supply Chain Integration in Vietnam. Zagreb International Review of Economics \& Business, 20(SCI), 1-11.

Chen, D., Ignatius, J., Sun, D., Zhan, S., Zhou, C., Marra, M., \& Demirbag, M. (2019). Reverse logistics pricing strategy for a green supply chain: A view of customers' environmental 
awareness. International Journal of Production Economics, 217, 197-210. https://doi.org/10.1016/j.ijpe.2018.08.031

Claro, D. P., Claro, P. B. D., \& Hagelaar, G. (2006). Coordinating collaborative joint efforts with suppliers: the effects of trust, transaction specific investment and information network in the Dutch flower industry. Supply Chain Manage, 11(3), 216-224. https://doi.org/10.1108/13598540610662112

Darnall, N. (2003). Motivations for participating in a voluntary environmental initiative: The multi-state working group and EPA's EMS pilot program. In: S. Sharma, \& M. Starik (Eds.), Research in corporate sustainability (pp. 123-154). Boston, MA: Edward Elgar Publishing.

Darnall, N., \& Edwards, D. (2006). Predicting the cost of environmental management system adoption: the role of capabilities, resources and ownership structure. Strategic Management Journal, 27(4), 301-320. https://doi.org/10.1002/ smj.518

Diabat, A. \& Govindan, K. (2011). An analysis of the drivers affecting the implementation of green supply chain management. Resour. Resources, Conservation and Recycling, $55(6), 659-667$.

Do, A. D., \& Luu, H. V. (2019). Developing a quality function deployment method for selecting and evaluating suppliers. Journal of Economics and Development, 262(4), 80-88. http:// $10.5267 /$ j.uscm.2020.6.005

Do, A. D., Nguyen, Q. V., Le, Q. H., \& Ta, V. L. (2020). Green supply chain management in Vietnam Industrial Zone: Province-Level Evidence. Journal of Asian Finance, Economics and Business, 7(7), 403-412. https://doi.org/10.13106/jafeb.2020.vol7.no7.403

Do, A. D., Nguyen, Q. V., Nguyen, D. U., Le, Q. H., \& Trinh, D. U. (2020). Green supply chain management practices and destination image: Evidence from Vietnam tourism industry. Uncertain Supply Chain Management, 8(7), 371-378.

Fahimnia, B., Sarkis, J., \& Davarzani, H. (2015). Green supply chain management: A review and bibliometric analysis. International Journal of Production Economics, 162(C), 101-114. http:// 10.1016/j.ijpe.2015.01.003

Gonzalez-Torre, P., Alvarez, M., Sarkis, J., \& Adenso-Diaz, B. (2010). Barriers to the implementation of environmentally oriented reverse logistics: Evidence from the automotive industry sector. British Journal of Management, 21(4), 889904. https://doi.org/10.1111/j.1467-8551.2009.00655.x

Hair Jr, J. F., Sarstedt, M., Hopkins, L., \& Kuppelwieser, V. G. (2014). Partial least squares structural equation modeling (PLS-SEM). European Business Review, 26(2), 106-121.

Hair Jr, J. F., Sarstedt, M., Matthews, L. M., \& Ringle, C. M. (2016). Identifying and treating unobserved heterogeneity with FIMIXPLS: Part I-method. European Business Review. https://doi. org/10.1155/2018/6561417

Handfield, R. B., Walton, S. V., \& Melnyk, S. A. (1996). Green supply chain: best practices from the furniture industry. In: Proceedings of the Annual Meeting of the Decision Science Institute (pp. 1295-1297).
Handfield, R., Sroufe, R., \& Walton, S. (2005). Integrating environmental management and supply chain strategies. Business Strategy and the environment, 14(1), 1-19. https://doi.org/10.1002/bse.422

Hart, S. L. (1995). A natural-resource-based view of the firm. Academy of Management Review, 20(4), 986-1014. https:// www.jstor.org/stable/258963

Henseler, J., Ringle, C. M., \& Sarstedt, M. (2015). A new criterion for assessing discriminant validity in variance-based structural equation modeling. Journal of the Academy of Marketing Science, 43(1), 115-135.

Hoejmose, S. U., Grosvold, J., \& Millington, A. (2014). The effect of institutional pressure on cooperative and coercive "green" supply chain practices. Journal of Purchasing and Supply Management, 20(4), 215-224. http://dx.doi.org/10.1016/j.pursup.2014.07.002

Holt, D., Anthony, S., \& Viney, H. (2001). Supporting environmental improvements in SMEs in the UK. Greener Management International, 33(6), 29-49. https://doi.org/10.1016/j. sbspro.2014.10.028

Krause, D. R., Handfield, R. B., \& Tyler, B. B. (2007). The relationships between supplier development, commitment, social capital accumulation and performance improvement. Journal of Operations Management, 25(2), 528-545. https:// doi.org/10.1016/j.jom.2006.05.007

Laari, S., Toyli, J., Solakivi, T., \& Ojala, L. (2016). Firm performance and customer-driven green supply chain management. Journal of Cleaner Production, 112(3), 1960-1970. http://dx.doi. org/10.1016/j.jclepro.2015.06.150

Lambert, D. M., \& Enz, M. G. (2015). We must find the courage to change. Journal of Business Logistics, 36(1), 9-17. https://doi. org $/ 10.1111 / \mathrm{jbl} .12078$

Large, R. O., \& Thomsen, C. G. (2011). Drivers of green supply management performance: Evidence from Germany. Journal of Purchasing \& Supply Management, 17(3), 176-184. http:// http://www.ijmp.jor.br/index.php/ijmp/article/view/789

Lawson, B., Tyler, B. B., \& Cousins, P. D. (2008). Antecedents and consequences of social capital on buyer performance improvement. Journal of Operations Management, 26(3), 446460. https://isiarticles.com/bundles/Article/pre/pdf/4097.pdf

Le, T. T. (2020). The effect of green supply chain management practices on sustainability performance in Vietnamese construction materials manufacturing enterprises. Uncertain Supply Chain Management, 8(1), 43-54.

Lee, A. Y. (2015). The effects of green supply chain management on the supplier's performance through social capital accumulation. Supply Chain Management, 20(1), 42-55.

Lee, S. Y. (2008). Drivers for the participation of small and mediumsized suppliers in green supply chain initiatives. Supply Chain Management, 13(3), 185-198.

Luk, C. L., Yau, O. H. M., Sin, L. Y. M., Tse, A. C. B., Chow, R. P. M., \& Lee, J. S. Y. (2008). The effects of social capital and organizational innovativeness in different institutional contexts. Journal of International Business Studies, 39(4), 589-612. 
Luthra, S., Garg, D., \& Haleem, A. (2015). An analysis of interactions among critical success factors to implement green supply chain management towards sustainability: An Indian perspective. Resources Policy, 46(P1), 37-50. Doi: 10.1016/j. resourpol.2014.12.006

Mamdouh M. H., O., Kadry E., K., \& Elahmady, B. (2018). Impact of sustainable supply chain management practices on Egyptian companies' performance. European Journal of Sustainable Development, 7(4), 119-130. https://doi.org/10.14207/ ejsd.2018.v7n4p119

Mentzer, J. T., DeWitt, W., Keebler, J. S., Min, S., Nix, N. W., Smith, C. D., \& Zacharia, Z.G. (2001). Defining supply chain management. Journal of Business Logistics, 22(2), 1-25. https://doi.org/10.1002/j.2158-1592.2001.tb00001.x

Min, H., \& Galle, W. P. (1997). Green purchasing strategies: trends and implications. International Journal of Purchasing and Materials Management, 33(2), 10-17. https://doi.org/10.1111/ j.1745-493X.1997.tb00026.x

Mitra, S., \& Datta, P. P. (2014). Adoption of green supply chain management practices and their impact on performance: An exploratory study of Indian manufacturing firms. International Journal of Production Research, 52(7), 2085 - 2107. https:// doi.org/10.1080/00207543.2013.849014

Porter, M.E. (1990). The Competitive Advantage of Nations. New York, NY: The Free Press.

Ramus, C. A., \& Steger, U. (2000). The roles of supervisory support behaviors and environmental policy in employee "ecoinitiatives" at leading-edge European companies. Academy of Management Journal, 43(4), 605-626. https://www.jstor.org/stable/1556357

Rao, P., \& Holt, D. (2005). Do green supply chains lead to competitiveness and economic performance? International Journal of Operations \& Production Management, 25(9), 898-916. http:// doi/10.1108/01443570510613956/full/html

Sarkis, J. (1998). Evaluating environmentally conscious business practices. European Journal of Operational Research, 107(1), 159-174. https://doi.org/10.1016/S0377-2217(97)00160-4

Sarkis, J. (2003). A strategic decision framework for green supply chain management. Journal of Cleaner Production, 11(4), 397409. https://doi.org/10.1016/S0959-6526(02)00062-8

Sarkis, J. (2012). A boundaries and flows perspective of green supply chain management. Supply Chain Management, 17(2), 202-216. http:// doi/10.1108/13598541211212924/full/html

Sarkis, J., Zhu, Q., \& Lai, K. H. (2011). An organizational theoretic review of green supply chain management literature. International Journal of. Production Economics, 130(1), 1-15.

Seuring, S., \& Muller, M. (2008). From a literature review to a conceptual framework for sustainable supply chain management. Journal of Cleaner Production, 16(15), 16991710. https://doi.org/10.1016/j.jclepro.2008.04.020

Sharma, S., Pablo, A. L., \& Vrendenburg, H. (1999). Corporate environmental responsiveness strategies: The importance of issue interpretation and organizational context. Journal of Applied Behavioral Science, 35, 87-108.

Srivastava, S. K. (2007). Green supply-chain management: A state-of-the-art literature review. International Journal of Management Reviews, 9(1), 53-80.

Stock, J. R., \& Boyer, S. L. (2009). Developing a consensus definition of supply chain management: A qualitative study. International Journal of Physical Distribution \& Logistics Management, 39(8), 690-711. http://dx.doi.org/10.1108/09600030910996323

Ta V. L., Le Q. H., Nguyen T. L. H., Phan T. T. \& Do A. D. (2020). Investigating foreign direct investment attractive factors of Korean direct investment into Vietnam. Journal of Asian Finance, Economics and Business, 7(6), 117-125. https://doi. org/10.13106/jafeb.2020.vol7.no6.117

Tate, W. L., Ellram, L. M., \& Dooley, K. J. (2012). Environmental purchasing and supplier management (EPSM): Theory and practice. Journal of Purchasing \& Supply Management, 18(3), 173-188.

Tsai, W. P., \& Ghoshal, S. (1998). Social capital and value creation: The role of intrafirm networks. Academy of Management Journal, 41(4), 464-476. https://doi.org/10.5465/257085

Wang, Z., \& Sarkis, J. (2013). Investigating the relationship of sustainable supply chain management with corporate financial performance. International Journal of Productivity and Performance Management, 62(8), 871-888. https://doi. org/10.1108/IJPPM-03-2013-0033

Webb, L. (1994). Green purchasing: Forging a new link in the supply chain. RESOUR, 1(6), 14-18.

Zhu, Q. H., Sarkis, J., \& Geng, Y. (2005). Green supply chain management in China: Pressures, practices and performance. International Journal of Operations \& Production Management, 25(5), 449-468. https://doi.org/10.1108/01443570510593148

Zhu, Q. H., Sarkis, J., \& Lai, K.H. (2007). Initiatives and outcomes of green supply chain management implementation by Chinese manufacturers. Journal of Environmental Management, 85(1), 179-189. doi: 10.1016/j.jenvman.2006.09.003.

Zhu, Q. H., Sarkis, J., Cordeiro, J. J., \& Lai, K. H. (2008). Firmlevel correlates of emergent green supply chain management practices in the Chinese context. Omega, 36(4), 577-591.

Zhu, Q., \& Sarkis, J. (2004). Relationships between operational practices and performance among early adopters of green supply chain management practices in Chinese manufacturing enterprises. Journal of Operations Management, 22(3), 265-289. https://doi.org/10.1016/j.jom.2004.01.005

Zhu, Q., \& Sarkis, J. (2006). An inter-sectoral comparison of green supply chain management in China: Drivers and practices. Journal of Cleaner Production, 14(6), 472-486. https://doi. org/10.1016/j.jclepro.2005.01.003

Zhu, Q., Sarkis, J., \& Lai, K. H. (2013). Institutional-based antecedents and performance outcomes of internal and external green supply chain management practices. Journal of Purchasing \& Supply Management, 19(2), 106-117. http:// doi:10.1016/j.pursup.2012.12.001 